\title{
Defining recovery from anorexia nervosa: a Delphi study to explore practitioners' views
}

\author{
Lisa Dawson*, Paul Rhodes, Stephen Touyz \\ From 2013 ANZAED Conference: Inspiring Change: Person and Context \\ Melbourne, Australia. 23-24 August 2013
}

There is no consensus as how best to define and measure recovery from anorexia nervosa (AN). Definitions of recovery vary vastly between studies, making them difficult to compare. This has been identified as a major barrier in the field. The aim of the current study was to explore how best to define and measure recovery according to expert researchers and clinicians. This research used the Delphi technique, a method used to gain consensus on an issue. Twenty leading international experts in the field completed three rounds of online questionnaires. This was a multi-stage process with each round building on the previous round until consensus was achieved amongst the panel. Preliminary findings have revealed that experts in the field define recovery from AN as more than the restoration of weight and absence of eating disordered behaviours. Participants suggested that recovery also includes experiencing normal levels of body dissatisfaction and improved quality of life and social functioning. Full findings are reported and the research and clinical implications for establishing a consensus definition in the field are discussed.

This abstract was presented in the Anorexia Nervosa Characteristics and Treatment stream of the 2013 ANZAED Conference.

Published: 14 November 2013

doi:10.1186/2050-2974-1-S1-041

Cite this article as: Dawson et al.: Defining recovery from anorexia

nervosa: a Delphi study to explore practitioners' views. Journal of Eating

Disorders 2013 1(Suppl 1):041.

\footnotetext{
* Correspondence: lisa.dawson@sydney.edu.au

The University of Sydney, Australia
}

Submit your next manuscript to BioMed Central and take full advantage of:

- Convenient online submission

- Thorough peer review

- No space constraints or color figure charges

- Immediate publication on acceptance

- Inclusion in PubMed, CAS, Scopus and Google Scholar

- Research which is freely available for redistribution 